\title{
O primado da disposição: Dziga Vertov e a exaltação do homem soviético
}

\author{
Fábio Ávila Arcanjo \\ Doutor em Estudos Linguísticos pela Universidade Federal de Minas Gerais (UFMG), Brasil \\ orcid.org/0000-0002-8525-9737
}

Este artigo objetiva analisar o importante trabalho cinematográfico executado pelo cineasta russo Dziga Vertov, com destaque para o fundamental documentário Um homem com uma câmera, produzido em 1929. Seu cinema está inserido em algo definido por Sergei Eisenstein como parti-pris - tomada de posição -, um tipo de produção fílmica que pensa por imagens (XAVIER, 2014), refutando a linearidade própria da decupagem clássica calcada em um tipo narrativorepresentativo. Os principais eixos defendidos por Vertov são: Kino-Pravda (cinema verdade); Kino-Glaz (Cine-Olho), com a montagem sendo estruturada de forma dialética. Esse último ponto terá nossa atenção, considerando o sistema retórico e as quatro partes da retórica - invenção, disposição, elocução e ação (REBOUL, 2004). Partimos do princípio de que o cinema praticado pelo cineasta russo é sedimentado na disposição e na mobilização do gênero epidítico, materializado na exaltação dos valores soviéticos. Esses eixos serão contemplados em nossa discussão.

Palavras-chave: Cinema. Retórica. Disposição. Montagem.

\section{La primacía de la disposición: Dziga Vertov y la exaltación del hombre soviético}

Este artículo tiene como objetivo analizar el importante trabajo cinematográfico realizado por el cineasta ruso Dziga Vertov en el que se destaca el fundamental documental El hombre de la cámara, producido en 1929. Su cine está insertado en algo definido por Sergei Eisenstein como parti-pris - toma de posición -, un tipo de producción fílmica que piensa por imágenes (XAVIER, 2014), refutando la linealidad propia del decoupage clásico calcada en un tipo narrativorepresentativo. Los principales ejes defendidos por Vertov son: Kino-Pravda (cine verdad); Kino-Glaz (Cine-Ojo), con el montaje que es estructurado de forma dialéctica. Este último punto tendrá nuestra atención en el que consideraremos el sistema retórico y las cuatro partes de la retórica - invención, disposición, elocución y acción (REBOUL, 2004). Partimos del principio de que el cine practicado por el cineasta ruso está sedimentado en la disposición y en la movilización del género epidíctico, materializado en la exaltación de los valores soviéticos. Esos ejes serán contemplados en nuestra discusión.

Palabras clave: Cine. Retórica. Disposición. Montaje.

\section{The primacy of the disposition: Dziga Vertov and the exaltation of the Soviet man}

This article aims to analyze the important cinematographic work executed by the russian filmmaker Dziga Vertov, with emphasis on the fundamental documentary Man with a movie camera, produced in 1929. His cinema is inserted in something defined by Sergei Eisenstein as parti-pris - taking position -, a type of filmic production that thinks through images (XAVIER, 2014), refuting the linearity of classical decoupage based on a narrative-representative type. The main axes defended by Vertov are Kino-Pravda (true cinema) and Kino-Glaz (cine-eye), with the edition being structured in a dialectical way. This last point will have our attention, considering the rhetorical system and the four parts of rhetoric invention, disposition, elocution and action (REBOUL, 2004). We assume that the cinema practiced by the Russian filmmaker is grounded in the disposition and in the mobilization of the epideictic genre, materialized in the exaltation of Soviet values. These axes will be contemplated in our discussion.

Keywords: Cinema. Rhetoric. Disposition. Edition. 


\section{Introdução}

Em uma afirmação nodal, que inaugura seu livro, Olivier Reboul assevera que "a retórica é anterior à sua história, e mesmo a qualquer história, pois é inconcebível que os homens não tenham utilizado a linguagem para persuadir." (REBOUL, 2004, p. 1). Pois bem, tendo em mente essa prerrogativa, é mister ponderar que, embora Aristóteles seja o responsável pelo primeiro modelo sistemático de retórica, anteriormente ao advento da atividade filosófica do estagirita, a retórica esteve em pauta, seja em uma visada prática e pragmática (tratativa concedida pelos sofistas) seja em um mecanismo de rejeição, em função de seu desapego à verdade e vinculação à verossimilhança (visada platônica).

O que se percebe, a partir do que foi ensaiado até o momento, é a existência de uma trajetória da retórica que remonta há mais de 2500 anos, apenas atentando para o recorte temporal pontuado pela existência de registros, já que, conforme Olivier Reboul, a persuasão pela linguagem acompanha a vida humana desde tempos imemoriais. Sem embargo, Aristóteles, em nosso empreendimento, exerce um papel fundamental, justamente pela formalização. O que ele faz é reabilitar a retórica, a integrando em uma visão sistemática do mundo e a transformando em um sistema, comumente completado por sucessores (entre eles, os latinos, como Cícero e Quintiliano), mas jamais drasticamente modificado (REBOUL, 2004).

A primeira parte de nosso artigo é dedicada às fases do discurso do sistema retórico, em que iremos conceder um destaque especial para a categoria da disposição, justamente por analisarmos o trabalho cinematográfico desenvolvido por um cineasta atrelado à condição de teórico da montagem. Concatenaremos, destarte, a disposição (vinculada ao sistema retórico aristotélico) com a montagem cinematográfica, sem perder de vista que as categorias que compõem o sistema - invenção, disposição, elocução, ação e memória (esta última, acrescentada séculos mais tarde pelos retóricos latinos) não são estanques. Ao trazer a ideia de primazia, objetivamos explicitar que existe um destaque, isto é, uma focalização, que não interdita (seria impossível) as outras categorias. Nossa análise partirá, em vista disso, da disposição (montagem), sem desvalorizar os outros elementos. A questão que se coloca é: como isso será realizado?

Essa é a segunda parte do artigo, que primará em conferir ressonância às discussões desenvolvidas, tendo como base a materialidade discursiva da obra de Dziga Vertov, com destaque para o basilar - Um homem com uma câmera (1929). Como aporte teórico, faremos um diálogo entre a teorização concebida pelo próprio Dziga Vertov e pesquisadores como Bill Nichols (2014), que preconiza a existência de uma 
retoricidade inerente ao gênero documentário e Ismail Xavier (2014), responsável por uma abordagem relevante acerca da linguagem cinematográfica.

Um ponto que nos parece fundamental é perceber que o cinema traz, por intermédio de suas ferramentas, potencialidades que ultrapassam a visão única, encerrada em lógicas de continuidade e linearidade, próprios das prerrogativas defendidas pelo método clássico ${ }^{1}$. Não se pode desconsiderar que qualquer estética é envolta por posições ideológicas e, nesse sentido, o problema não se localiza "no dilema ideologia/não-ideologia, mas na forma como cada ideologia (e cada estética) particular estabelece seus vínculos e define os interesses com os quais ela assume compromisso." (XAVIER, 2014, p. 67). Nesse sentido, o cinema de Dziga Vertov não se configura pela neutralidade. Ao contrário, o que seus filmes, e Um homem com uma câmera é um ótimo exemplo, trazem como característica é a defesa dos valores soviéticos, emergentes em uma estruturação notadamente retórica, pois eles visam à exaltação (por meio da persuasão) da mentalidade progressista vigente em seu país.

\section{0 sistema retórico e a relação entre disposição e montagem cinematográfica}

Conforme expressamos até o presente momento, as fases do discurso circunscritas ao sistema retórico configuram-se em dispositivos inerentes a qualquer ato de linguagem. No instante em que se faz uso da palavra, o orador, de alguma forma, lida com essas fases, designadas pelo filósofo belga Michel Meyer (2007) de andares do edifício retórico.

Em primeiro lugar, é preciso ter a ideia, isto é, recortar em meio aos elementos dóxicos (AMOSSY, 2018) circulantes, o que vai ser desenvolvido. Reboul, no que tange à invenção, observa que "antes de empreender um discurso, é preciso perguntar-se sobre o que ele deve versar, portanto, sobre o tipo de discurso, o gênero que convém ao assunto" (REBOUL, 2004, p. 44). Nesse particular, entram em cena os gêneros do discurso (na retórica clássica, deliberativo, legislativo e judiciário); as provas retóricas (ethos, pathos e logos); e os lugares (topoi). Para Reboul (2004), essa fase prima em conjugar a noção de inventário (argumentos e procedimentos disponíveis) com invenção (criação de argumentos e de instrumentos de prova).

\footnotetext{
1 Quando se pensa em estética clássica, a primeira noção que salta aos olhos é a de decupagem clássica, sendo decupagem o procedimento de decomposição do filme (suas sequências e cenas) em planos (extensão de filme compreendida entre dois cortes). No entendimento de Ismail Xavier, "o que caracteriza a decupagem clássica é seu caráter de sistema cuidadosamente elaborado, de repertório lentamente sedimentado na evolução histórica, de modo a resultar num aparato de procedimentos precisamente adotados para extrair o máximo rendimento dos efeitos da montagem e ao mesmo tempo torná-la invisível" (XAVIER, 2014, p. 32).
} 
A elocução possui relação com o plano de expressão, podendo ser examinada como um ornamento do discurso. Nesse particular, estamos diante de uma categoria intimamente ligada à noção de estilo, que perspectiva uma implicação basilar, a saber, a eficácia, atinente à adaptação ao assunto. No cinema soviético, por exemplo, praticado por nomes como Sergei Eisenstein e Dziga Vertov, a comicidade, talvez, seja uma estratégia pouco adequada, ou pelo menos, controversa, dado o teor daquilo que é defendido por tais cineastas. Percebemos, então, a existência de uma espécie de condicionamento no emprego de determinado modus operandi, sendo o orador, ou o cineasta, em termos de discurso fílmico, eficaz aquele que "adota o estilo que convém a seu assunto: o nobre para comover (movere), sobretudo na peroração; o simples para informar e explicar (docere), sobretudo na narração e na confirmação; o ameno para agradar (delectare), sobretudo no exórdio e na digressão" (REBOUL, 2004, p. 62). Em Aristóteles, encontramos dizeres que referendam o raciocínio de Olivier Reboul, uma vez que o estagirita atesta que "o estilo apresentará a conveniência desejada se for apto a expressar as emoções e o caráter, e se mantiver a relação estreita com o assunto" (ARISTÓTELES, 2011, p. 227).

A ação, e novamente Reboul (2004) baliza nossa problematização, pressupõe a colocação em cena da atividade retórica. O pesquisador francês a caracteriza como um arremate, que mobiliza a inscrição das fases do discurso. Quando se tem em vista, por exemplo, o discurso cinematográfico, a ação seria o procedimento de enunciação fílmica (mise-en-scène), que materializa as ferramentas linguageiras desenvolvidas pelos cineastas. Essa mobilização, vale ressaltar, está relacionada com os imaginários circulantes, no tocante aos saberes, crenças e valores. É daí que racionamos a partir de uma conjugação entre o inventário (aquilo que circula) e a invenção (iniciativa em abordar certos assuntos, por meio de estratégias específicas).

Antes de apresentarmos a fase discursiva proeminente em nosso empreendimento, é válido mencionar algo que se configura em acréscimo por parte dos retóricos latinos (principalmente, Cícero e Quintiliano), a saber, a memória. Nessa concepção, tal fase é vinculada à capacidade de memorização, já que "é 'dominando' o discurso que temos mais condições de ajustar-nos às objeções e de improvisar. Portanto, em vez de se opor à criatividade, a memória é fator essencial para ela" (REBOUL, 2004, p. 68). O fato é que, embora seja importante memorizar dados, principalmente se estivermos diante de debates públicos, essa necessidade de fixar informações específicas na mente foi dirimida, em função de uma maior circulação de informações e, por conseguinte, maior facilidade de armazenamento.

É plausível, levando em conta esse adendo, adaptar a concepção latina de memória, trazendo a ideia contemporânea de memória discursiva. Tal noção está conectada à doxa, possuindo, diante disso, uma relação direta com a invenção, uma 
vez que a criação de argumentos e instrumentos de prova depende diretamente da disponibilidade, considerando que algo circula anteriormente. O excerto precedente é basilar para entender essa noção de memória, portadora de

[...] características, quando pensada em relação ao discurso. E, nessa perspectiva, ela é tratada como interdiscurso. Este é definido como aquilo que fala antes, em outro lugar, independentemente. Ou seja, é o que chamamos memória discursiva: o saber discursivo que torna possível todo dizer e que retorna sob a forma do préconstruído, o já-dito que está na base do dizível, sustentando cada tomada da palavra (ORLANDI, 2015, p. 29).

Nesse sentido, ao trazermos a categoria da disposição, normalmente apontada como o segundo andar do edifício retórico, deslocada em nosso texto em função de sua primazia, não se pode perder de vista que ela é estruturada tendo como base o que circula em relação à intencionalidade do orador. Dziga Vertov, por exemplo, organiza sua formatação estética, estando atrelado a um movimento que vigorava em seu entorno. É claro que o cineasta russo contribui na solidificação de suas bases, mas isso se dá em consonância com os valores em vigor naquele país e naquele momento. Façamos uma pequena análise a respeito dessa fase do discurso, para em seguida, apresentar a noção de montagem cinematográfica.

A disposição, categoria do ritmo e do ordenamento, deve ser avaliada como uma visada de focalização. Ela se relaciona à estruturação e à escolha, direcionando a seleção temática (o que é relevante para ser enfatizado) e o recorte momentâneo (como iniciar, desenvolver e finalizar determinados atos de linguagem). Notemos que isso se aplica, tanto em discursos na modalidade verbal, quanto em produções audiovisuais. Aristóteles (2011) observa que o discurso comporta duas partes, associadas à indicação do assunto tratado e ao procedimento de demonstração desse assunto, que passam, necessariamente, no entendimento do filósofo, pelos seguintes estágios: prólogo (exórdio), exposição, demonstração (que comporta estratégias como refutação e controvérsia) e epílogo (peroração).

Sobre a importância da disposição, recorramos a Olivier Reboul, pois ele afirma que "graças a ela, o orador faz o auditório encaminhar-se pelas vias e pelas etapas que escolheu, conduzindo-o assim para o objetivo que propôs. Essa metáfora do caminho é confirmada por termos como 'preâmbulo' (sinônimo de exórdio) ou 'digressão' (desvio do rumo)" (REBOUL, 2004, p. 60). Os estágios observados pelo pesquisador francês são similares ao que foi elaborado por Aristóteles, e o que é nomeado pelo estagirita de exposição e demonstração, recebe, em Reboul (2004), as designações de narração "exposição dos fatos referentes à causa, exposição aparentemente objetiva, mas sempre orientada segundo as necessidades da acusação ou da defesa" (REBOUL, 2004, p. 56); confirmação - "[...] o conjunto de provas, seguido por uma refutação (refutatio), que destrói os argumentos adversários" (REBOUL, 2004, p. 57); e digressão, 
que "tem como função distrair o auditório, mas também apiedá-lo ou indigná-lo; pode até servir como evocação histórica do passado longínquo" (REBOUL, 2004, p. 59).

Em relação à peroração, o filósofo francês observa a presença de três componentes, passíveis de proeminência em determinados discursos. O primeiro, amplificação, é, particularmente, relevante em nosso gesto de leitura, pois Dziga Vertov se insere na esfera do discurso epidítico, envolto à valorização e, claro, amplificação dos ideais soviéticos. Lidaremos com esse aspecto mais à frente. O segundo componente é a paixão, também fortemente presente nos filmes de Dziga Vertov, alusiva à mobilização de determinadas emoções no auditório. Por fim, temos a recapitulação, que é atinente à concatenação das ideias, como forma de conseguir os objetivos traçados pelo orador. Diante do exposto, é notável que "a peroração é o momento por excelência em que a afetividade se une à argumentação, o que constitui a alma da retórica" (REBOUL, 2004, p. 59).

Parece-nos pertinente trazer o seguinte questionamento: qual a importância da fase discursiva da disposição? O que ela nos permite apreender? Em nosso entendimento, analisar tal categoria tem como requisito a compreensão dos efeitos de sentido suscitados por determinados oradores. No caso do discurso cinematográfico, entender as potencialidades da montagem empregada por determinados cineastas acarreta na observação dos valores, possivelmente, cultuados por eles e, ainda, como tais valores encontram ressonância em suas produções fílmicas. A montagem está distante de ser um recurso neutro, pautado apenas pelo ordenamento. Há, em seu emprego, questões políticas, ideológicas e estéticas, que serão mais bem verificadas no decorrer de nosso artigo.

\subsection{A montagem cinematográfica}

Raciocinar a respeito da linguagem cinematográfica implica lidar com duas operações básicas, acionadas na construção de um filme (XAVIER, 2014). Em primeiro lugar, temos a filmagem, um movimento delimitado pelo registro imagético. Aqui, temos alguns recursos fundamentais na elaboração de uma cena, tais como os enquadramentos e ângulos de câmera, além dos tipos de planos a serem adotados ${ }^{2}$. A montagem é apresentada em segundo lugar, compreendendo a visada a ser adotada por certos projetos fílmicos, tendo em vista a inscrição de duas impressões estéticas fulcrais: continuidade e descontinuidade.

\footnotetext{
2 Em Xavier (2014), encontramos tipificações de planos mais comuns no gênero cinematográfico. Citemos: Plano geral (câmera registrando todo o espaço de ação e posicionada em ambientes de grande amplitude); Plano médio (usado, normalmente, para ambientes de interiores); Plano americano (ponto de vista em que as figuras humanas são mostradas até a cintura); e Primeiro plano - close-up (usado para mostrar em detalhes certos elementos, tais como objetos ou partes do corpo de figuras humanas).
} 
Para os mais radicais na admissão de uma pretensa objetividade do registro cinematográfico, tendentes a minimizar o papel do sujeito no registro, a montagem será o lugar por excelência da perda da inocência. Por outro lado, a descontinuidade do corte poderá ser encarada como um afastamento frente a uma suposta continuidade de nossa percepção do espaço e do tempo na vida real (aqui estaria implicada uma ruptura com a semelhança). Veremos que tal "ruptura" é perfeitamente superada por um determinado método de montagem, com vantagens no que se refere ao efeito de identificação (XAVIER, 2014, p. 24).

A narrativa clássica lança mão de uma montagem que prima pela continuidade, a partir de uma aparente invisibilidade da montagem. Para dar conta desse expediente, é válido resgatar o conceito de decupagem clássica, voltada, em tese, para a manipulação emocional do espectador. Isso se dá mediante recursos impulsionadores de fluência e ritmo, que emulam uma progressão contínua. Dentre eles, destaquemos a montagem paralela (empregada para colocar em fricção acontecimentos coincidentes); uso da profundidade (que permite uma visualização ampla, no tocante ao que está sendo enquadrado pela câmera); e a câmera subjetiva ("coloca" o espectador dentro da cena, quando a câmera assume o ponto de vista de uma das personagens). É sabido que tais recursos podem estar a serviço de projetos descontínuos e propositadamente desordenados, contudo, eles emergem na linguagem clássica, oferecendo cadência e linearidade e, por conseguinte, suscitando o chamado efeito-janela.

Eu havia definido decupagem como simplesmente uma decomposição da cena em planos; agora é preciso lembrar o que está implicado nesta decomposição. Em primeiro lugar, a rigor, eu deveria falar em decupagem/montagem, pois uma pressupõe a outra - são logicamente equivalentes. O uso dos dois termos deve-se a uma ordem cronológica encontrada na prática, onde decupagem identifica-se com a fase de confecção do roteiro do filme e montagem, em sentido estrito, é identificada com as operações materiais de organização, corte e colagem dos fragmentos filmados (XAVIER, 2014, p. 36).

O que nos interessa, neste artigo, é lidar com a noção de montagem, que se municia da decupagem para programar, no caso do modelo clássico, o efeito-janela, pautado pelo naturalismo circunscrito "à construção efetiva de um espaço-tempo próprio ao cinema" (ibidem). Esse naturalismo é, justamente, o conjunto de procedimentos específicos de uma produção cultural inerente ao direcionamento ideológico adotado, por exemplo, pelo cinema hollywoodiano, que traz como característica nodal a montagem invisível. Uma das expressões definidoras dessa mise-en-scène é "american way of life", que significa, precisamente, a proliferação de valores e crenças defendidos pela classe burguesa. Admitamos, destarte, a possibilidade de existirem projetos que se municiam desse mecanismo para, em seguida, desconstruí-lo.

Enfatizamos, anteriormente, que o efeito-janela, enfocando a produção industrial de Hollywood, é uma incursão do chamado naturalismo, sendo um modelo que parte de uma 
[...] convergência radical entre a construção de um discurso que se quer transparente (efeito de janela/fluência narrativa) e a modelagem precisa de uma dupla máscara: para propor uma ideologia como verdade, tal máscara insinua-se na superfície da tela (produzindo os efeitos ilusionistas) e insinua-se, na profundidade e na duração produzidas por estes efeitos (produzindo as convenções do universo imaginário no qual o espectador mergulha) (XAVIER, 2014, p. 46).

É conveniente estabelecer uma diferenciação entre as escolas cinematográficas do naturalismo e do realismo. A primeira se vincula, conforme indicamos anteriormente, ao cinema hollywoodiano, mais particularmente em filmes produzidos em escala industrial, cujo direcionamento é reverberar valores burgueses. O realismo aciona modus operandi diferentes, fazendo-se presente em profusos aportes teóricos e estéticos. A questão a ser posta é: qual o grau de implicação da montagem nesse vasto horizonte? Em nosso entendimento, ele é total, uma vez que a disposição do material filmado constitui o cerne do que será defendido ou contestado.

$\mathrm{Na}$ corrente do realismo, vale destacar o nome de Lev Kulechov, identificado como o inaugurador da teoria da montagem. O teórico russo defendia a perfeição e organicidade dramática. Ismail Xavier pontua que, no entendimento de Kulechov, a "montagem justa será aquela em que 'o relacionamento demonstra a essência do fenômeno que nos cerca, pois por trás da montagem há sempre uma intenção de classe'. Agora prevalece o critério ideológico [...] sobre o antigo critério do ritmo e da continuidade" (XAVIER, 2014, p. 2014, p. 51).

Na esteira do trabalho de Kulechov, destacam-se nomes como Vsevolod Pudovkin e Béla Balazs, que defendiam um movimento realista de base marxista. Pudovkin, tido como o principal discípulo de Kulechov, preconizava um cinema estruturado pelo critério da continuidade, conferindo primazia ao ritmo, ao equilíbrio de composição e à sucessão lógica, em prol de uma tomada de consciência. A exemplo de seu mestre, Pudovkin vê a montagem como o centro da arte cinematográfica, o que se justifica pelo fato das cenas serem construídas "a partir dos pedaços separados, em que cada um concentra a atenção do espectador apenas naquele momento importante para a ação. A sequência desses pedaços não deve ser aleatória e sim corresponder à transferência natural de atenção de um observador imaginário" (PUDOVKIN, 1926 apud XAVIER, 2008, p. 60). Béla Balazs, teórico húngaro, pensava o cinema como o lugar de clareza e ordem. A palavra chave que define a arte cinematográfica para ele é continuidade, no sentido de que

[...] a imagem seccionada (ou "plano") deve ser ordenada e composta corretamente. Pode haver planos que escapam do todo, e a partir dos quais já não temos mais a sensação de estar no mesmo lugar, nem de ver a mesma cena como nos planos precedentes. Cabe ao diretor, se assim o desejar, fazer com que o espectador sinta a continuidade da cena, sua unidade no tempo e no espaço, mesmo que, para a 
orientação do espectador, ele ainda não tenha mostrado, nenhuma vez, a imagem total da cena (BALAZS, 1945 apud XAVIER, 2008, p. 88).

O realismo mobilizado por essas duas perspectivas parte do princípio de que a conscientização (desalienação) do espectador passa, necessariamente, pela coordenação e pela disposição linear das cenas, tendo a montagem a função de "excitar ou tranquilizar o espectador" (PUDOVKIN, 1926 apud XAVIER, 2008, p. 62). Há, ainda, outra vertente influente, chamada de realismo crítico, e defendida por teóricos como Umberto Barbaro e Guido Aristarco, cuja tarefa empreendida foi estabelecer "a abertura de um caminho entre o naturalismo - arte como cópia do real - e o idealismo subjetivista - arte como expressão da pura interioridade do artista" (XAVIER, 2014, p. 58).

Novamente, estamos diante de uma estética sedimentada pelos ideais marxistas, tendo a montagem a função de dispor as cenas de modo a defender determinados pontos de vista, além de denunciar valores encerrados no estilo de vida burguês. Em função disso, esse "autêntico realismo ocorre quando deste processo emerge um trabalho artístico que constitui uma crítica (exame) do real, que, em nossa época, traduzse na presença efetiva de um método particular de representação" (XAVIER, 2014, p. 59). A montagem, nesse caso, é linear, similar aos princípios da decupagem clássica, porém, longe de alienar o espectador, o que se busca é a consciência. Para tanto, a montagem prima pelo "respiro", com poucos cortes e uma tentativa de integrar os silêncios e os cenários, com longas tomadas e uma apreensão psicológica das personagens. O melhor exemplo desse tipo de estética pode ser encontrado no neorrealismo italiano, praticado por nomes como Roberto Rossellini e Vittorio de Sica.

Por fim, sabedores de que a teoria da montagem é um campo amplo e calcado por diversos aportes teóricos, apresentemos, nesse curto panorama, o cinema de vanguarda, defendido por nomes como Jean Epstein e Fernand Léger. O que se percebe é a preeminência da descontinuidade, buscando "justamente quebrar as hierarquias de tal realismo, e sua maior aspiração é dissolver o homem e o social dentro de um universo homogêneo, onde a única ordem e a única inteligência possível se definem no nível da natureza" (XAVIER, 2014, p. 103). A montagem, nesse tipo de perspectiva, se opõe à linearidade, com o cinema se constituindo em um instrumento lírico e poético, considerando a vanguarda francesa. A vanguarda americana, igualmente pautada pela desconstrução, defende a tese de que cada fotograma traz em si uma significação, independentemente da disposição.

Esse dirimido percurso diacrônico serve para ilustrar a relação intrínseca entre a montagem e a mobilização de ideias, valores e crenças. Com isso, notamos que a disposição é indissociável da invenção. Veremos isso de forma mais detida no direcionamento ético e estético desenvolvido por Dziga Vertov. 


\section{Dziga Vertov, um homem com uma câmera}

Dziga Vertov, além de cineasta, foi um filósofo da linguagem cinematográfica. Em seu mais célebre filme Um homem com uma câmera ${ }^{3}$, produzido em 1929, encontramse os principais postulados adotados por esse diretor. Julgamos interessante estabelecer uma pequena análise acerca das condições de produção que propiciaram a enunciação do discurso fílmico construído pelo cineasta russo. A União Soviética vivenciava mais de dez anos de regime socialista, mas ainda havia a necessidade de consolidação de uma hegemonia cultural. Dois movimentos vanguardistas ${ }^{4}$ se mostraram importantes para o alcance desse objetivo, sendo, ainda, fundamentais para se pensar o espírito do tempo no qual Vertov estava inserido. Estamos falando do futurismo e do construtivismo. Os autores Nilson Assunção Alvarenga e Pedro Nogueira e Conceição afirmam que:

Assim como o movimento futurista, o construtivista tentava, em sua essência, absorver na arte as novas formas de percepção do mundo moderno, seu ritmo e sua rapidez. Como expressão da vida moderna, enquanto máquina e enquanto meio de representação, o cinema deveria cumprir um papel fundamental no sentido de instituir uma arte capaz de dar conta do mundo moderno e, ao mesmo tempo, levar o homem a abandonar as antigas visões de mundo, presas a modelos clássicos de representação social e artística (ALVARENGA; CONCEIÇÃO, 2009, p. 74-75).

Observar a mobilização desses movimentos implica na compreensão de que a arte responde a determinados anseios, valores e crenças. Em O homem com uma câmera, o que temos é um amálgama visual, que prima em suscitar no espectador um efeito de cosmopolitismo. Vertov objetiva reproduzir um dia da vida do chamado cidadão soviético, imerso em um mundo moderno, no qual existe uma convivência entre o homem e a máquina. Esse estado de coisas é sedimentado pela desconstrução do que é tido como arcaico. Estamos diante de um discurso epidítico que apresenta um mundo novo, em que há a refutação dos modelos clássicos e burgueses de representação artística.

Emmanuelle Danblon (2013) observa que o discurso epidítico encontra terreno a partir do momento em que se quer estabelecer uma configuração ética e estética do mundo, na medida em que há o engendramento de "uma atitude criativa de ordenamento do mundo, próprio da atividade narrativa "“" (DANBLON, 2013, p. 120, tradução nossa). Certamente, esse processo é condicionado pelos elementos dóxicos

\footnotetext{
${ }^{3}$ A produção dialoga com os filmes de sinfonia de cidades, que estavam em voga na época. São filmes que foram organizados buscando evidenciar o encantamento cosmopolita que as cidades do início do século XX estavam suscitando. Um ótimo exemplo é o alemão Berlim, sinfonia de uma metrópole (1927), dirigido por Walter Ruttmann.

4 Tais movimentos se caracterizam pela "ruptura em relação a parâmetros de representação clássica e com uma busca ligada não só ao presente, mas ao futuro da própria arte" (ALVARENGA; CONCEIÇÃO, 2009, p. 74).

${ }^{5}$ No original: "une aptitude créative d'ordonnacement du monde propre à l'activité narrative".
} 
circulantes, que orientam os atos de linguagem e, consequentemente, a circulação dos discursos.

Notemos, por exemplo, o funcionamento da decupagem clássica operacionalizada pelo cinema hollywoodiano. Há uma lógica de classe por trás daquele ordenamento. $\mathrm{O}$ que se quer transmitir, conforme apontamos anteriormente, é o american way of life, característico dos valores e crenças burgueses. O filósofo alemão Siegfried Kracauer defende que "os filmes de uma nação refletem a mentalidade desta, de maneira mais direta do que qualquer outro meio artístico" (KRACAUER, 1988, p. 17). O cinema, nessa perspectiva, seria uma caixa de ressonância e de propagação de valores e crenças, circulantes em um determinado estado de coisas.

Outro exemplo interessante é o cinema nazista orquestrado pelo ministro da propaganda Joseph Goebbels. Nesse tipo de filme, há a primazia de uma categoria retórica encerrada no gênero epidítico, a amplificação, sistematizada na exaltação do que era tido como virtuoso e valoroso, ao mesmo tempo em que se notava a construção da imagem do inimigo, igualmente sedimentada pela amplificação e pela repetição ${ }^{6}$. Se o cinema industrial americano primava por enaltecer os valores burgueses e o cinema nazista era pontuado pela exacerbação de uma intolerância institucionalizada, o cinema de Vertov, ao contrário, era marcado pela defesa do progressismo, da vanguarda, em suma, pela argumentação em prol do chamado homem soviético.

Consoante a esse pensamento, Emmanuelle Danblon observa que o discurso epidítico se constrói em um cenário de práticas discursivas engendradas pelos cidadãos, perfazendo a esfera propagandística, com vistas a alcançar um ordenamento político. A pesquisadora francesa assevera a existência de um dimensionamento racional por trás desse mecanismo, no sentido de que, claro, existem razões para, voltando o olhar para o nosso empreendimento, o cinema hollywoodiano mobilizar valores burgueses, o cinema nazista reverberar a intolerância e o ódio e o cinema soviético fazer resplandecer o progressismo. O discurso epidítico, desse modo, é desenvolvido mediante figurações de um real concebido por cineastas vinculados a esses modus operandi e tais figurações "encorajam, consolam e participam neste empreendimento geral da retórica de motivar o cidadão a agir no mundo que é o seu ${ }^{7 “}$ (DANBLON, 2013, p. 121, tradução nossa).

Tendo em conta a percepção do cinema como um veículo propagador de valores e ainda um campo propiciador dessas figurações de um real recortado, é válido chamar novamente a atenção para um elemento apresentado reiteradas vezes em nosso texto.

\footnotetext{
${ }^{6}$ Fiorin (2016) aponta que a figura da palilogia (repetição de versos e orações) carrega consigo a orientação de aumentar a extensão textual "para tornar mais intenso o sentido" (FIORIN, 2016, p. 127).

${ }^{7}$ No original: "[...] encouragent, consolent et participent à ce titre de cette entreprise générale de la rhétorique de motiver le citoyen à agir dans le monde qui est le sien".
} 
É um fato notório que Vertov se notabilizou por ser um cineasta que problematizou sua obra a partir de experimentações ocorridas na montagem. Podemos afirmar que tais experimentos o afastam da lógica adotada pela decupagem clássica. Nilson Assunção Alvarenga e Pedro Nogueira e Conceição observam que para Vertov, "a arte não está nos movimentos e sim na passagem entre eles" (ALVARENGA; CONCEIÇÃO, 2009, p. 76). E isso explica as razões pelas quais a teorização vertoviana acerca da supremacia da passagem entre os planos recebe o nome de teoria dos intervalos.

Como entender a estruturação desse tipo de cinema? É mister ponderar que a continuidade narrativa e a montagem invisível são elementos inexistentes. Não há, portanto, uma história linear. Um homem com uma câmera poderia narrar a trajetória de um cidadão russo, interagindo com as pessoas, tanto em casa, quanto no trabalho, com essa personagem enfrentando uma situação conflitiva, com um desenlace, positivo ou negativo. Não é bem essa estruturação que se vê na mise-en-scène vertoviana, pois nela há uma importância sendo concedida para cada frame, passível de ser lido de forma independente. Cada filigrana dessa tessitura fílmica reverbera a mensagem a ser transmitida e a montagem não se pauta pela continuidade narrativa, mas, sim, pela focalização daquilo que se quer defender. É uma teoria dos intervalos, em razão da montagem não construir uma espécie de ponte narrativa nos moldes clássicos. Estamos diante de um intervalo marcado, evidenciado, que, claro, se posiciona distante de uma invisibilidade.

Esse pensamento encontra amparo em uma hierarquização dos olhares, que engendra uma diferenciação entre o olho humano e o olho da câmera. Essa teorização culmina no chamado kino-glaz (cine olho), que consiste na câmera que capta "a vida de improviso sem a falsidade que o cinema clássico propunha" (ALVARENGA; CONCEIÇÃO, 2009, p. 76). Vertov acreditava no acentuado alcance da câmera em oposição ao olho humano, imperfeito pela limitação de alcance. Ele "enxergava no cinema a possibilidade de decifrar o mundo pela visão do olho da máquina, perfeito, novo e comunista" (ALVARENGA; CONCEIÇÃO, 2009, p. 80). Até o momento, apresentamos as leituras oferecidas por comentadores, mas ninguém melhor do que 0 próprio Dziga Vertov para explicar esse tipo de enunciação fílmica. Apresentemos suas palavras:

Assim, como ponto de partida, defendemos a utilização da câmera como Cine-Olho, muito mais aperfeiçoada do que o olho humano, para explorar o caos dos fenômenos visuais que preenchem o espaço. O Cine-Olho vive e se move no tempo e no espaço, ao mesmo tempo em que colhe e fixa impressões de modo totalmente diverso daquele do humano. A posição de nosso corpo durante a observação, a quantidade de aspectos que percebemos neste ou naquele fenômeno visual nada têm de coercitivo para a câmera, que percebe mais e melhor na medida em que é aperfeiçoada (VERTOV, 1923 apud XAVIER, 2008, p. 253-254). 
Nesse excerto, Vertov tece explicações a respeito da chamada Revolução Kinoks, uma expressão russa que condensa as palavras cine (kino) e olho (oko). Tais explicações foram alocadas na célebre Resolução do Conselho dos Três (Vertov, junto a sua esposa Elizaveta Svilova e seu irmão Mikhail Abramovich Kaufman), firmada no ano de 1922. Esse movimento deu origem a uma série de 23 curtas documentais, identificados como Kino-Pravda (cinema verdade), cujo mote era erigir modernas e experimentais perspectivas de trabalho cinematográfico, o que suscita uma nova percepção (estética e ética) do mundo. Esse modelo de filmagem e montagem traz como consequências a inscrição do movimento ininterrupto e o mergulho vertiginoso em acontecimentos visuais.

Em Xavier (2014), encontramos algumas asserções instigantes para entender a enunciação fílmica de Vertov e suas implicações. Três itens lexicais simbolizam esse projeto fílmico: estilização (da filmagem); disjunção (da montagem, que se organiza em meio à figuração do "real" captado pelo cineasta); e descontinuidade (ostensiva e articulada a uma diferente noção de enquadramento). É importante entender que a caracterização cinema verdade está longe de oferecer uma leitura que aproxime a estética de Vertov às chamadas escolas cinematográficas do naturalismo e do realismo. Caracterizar o cinema de Vertov como verdade acarreta na defesa de um novo homem vivo, com a sua realidade projetada no cinema, por meio da estilização, disjunção e descontinuidade. E isso pode ser alcançado - a defesa do homem soviético e progressista -, por meio dessa Revolução Kinoks, que traz a primazia do olho da câmera em detrimento do olho humano.

Ismail Xavier (2014) pontua que o cinema de Vertov visa à exposição de um processo mental, no sentido de que há a defesa de um pensamento dialético em processo. O que se quer empreender é a utilização do cinema como veículo para expor às massas o método dialético, em uma declaração de "guerra aberta aos filmes roteirizados e representados por atores" (NICHOLS, 2014, p. 60). Essa percepção encontra plena ressonância em Um homem com uma câmera, uma ode à vida progressista, destituído de personagens centrais e de uma narratividade clássica. O que o filme intenta realizar é o registro de um dia normal e corriqueiro na vida de uma cidade moderna russa.

Um dia de impressões visuais escoou-se. Como recriar as impressões desse dia num modo eficaz, num estudo visual? Se for preciso fotografar sobre a película tudo o que o olho viu, será o caos. Se montarmos com uma certa ciência, o que for fotografado ficará mais claro. Se jogarmos fora o supérfluo, ficará ainda melhor. Obteremos um resumo organizado das impressões visuais recebidas pelo olho comum. O olho mecânico, a câmera, que se recusa a utilizar o olho humano como lembrete, tateia no caos dos acontecimentos visuais, deixando-se atrair ou repelir pelos movimentos, buscando o caminho de seu próprio movimento ou de sua oscilação... (VERTOV, 1923 apud XAVIER, 2008, p. 256-257). 
O fragmento anterior estabelece uma contraposição entre o olho humano e o olho da câmera, apontando como cada um desses registros encenaria esse dia de impressões. Um homem com uma câmera pode ser pensado como a materialização da tese defendida pelo cineasta russo. Com isso, notam-se dois outros elementos prementes em sua obra: a reflexão ${ }^{8}$ e a metalinguagem. Jean-Louis Comolli observa a inscrição desse elemento logo no introito do filme: "A sala de cinema, caixa encantada. O homem com a câmera começa por abrir essa caixa vazia. O cameraman, descendo do alto de uma câmera filmada como monumento do mundo, passa por sua câmera por trás de uma cortina de teatro. O encantamento começa" (COMOLLI, 2008, p. 242).

Em que consiste esse encantamento? $O$ anfêmero de um dia comum na vida de habitantes de uma grande cidade? Essa seria uma plausível chave de resposta, contudo o que Vertov faz é uma ode à modernidade, à tecnologia, à ciência e, claro, à vida progressista. O que há em seu filme é a manifesta construção da imagem de si, junto à mobilização de valores, crenças e imaginários que circulam ao redor de um país em efervescência cultural. O Cine-Olho consiste, portanto, em uma "fusão de ciência e de atualidades cinematográficas, para que lutemos pela decifração comunista do mundo; tentativa de mostrar a verdade na tela pelo Cine-Verdade" (VERTOV, 1923 apud XAVIER, 2008, p. 262).

\section{Considerações finais}

Existem duas prerrogativas, discutidas pelo pesquisador americano Bill Nichols (2014), acerca da mobilização engendrada pelo cinema documental que nos parecem relevantes. Em primeiro lugar, o documentário é tido como um tratamento criativo da realidade, o que nos leva ao segundo ponto, já que esse gênero "reivindica uma abordagem do mundo histórico e a capacidade e intervenção nele, moldando a maneira pela qual o vemos" (NICHOLS, 2014, p. 69).

Essas asserções relacionam-se diretamente com a circulação de valores, o que abre brechas para leituras que inserem certos documentários no gênero epidítico. Um pressuposto basilar encontrado em Perelman e Olbrechts-Tyteca (2014) versa sobre a existência, ou melhor, a necessidade de um acordo prévio para que haja o efeito desejado pelo orador junto ao auditório, mirando a materialização da adesão às teses defendidas. É, pois, nesse acordo prévio que se encerram os valores, crenças e imaginários, circunscritos a um condicionamento externo dos dizeres.

\footnotetext{
8 Bill Nichols (2014) atesta a existência de seis modos de organização a serem aplicados no cinema do gênero documentário: poético, expositivo, observativo, participativo, performático e reflexivo. Esse último se adequa ao modus operandi adotado por Dziga Vertov, sendo o "modo de representação mais consciente de si mesmo e aquele que mais se questiona" (NICHOLS, 2014, p. 166).
} 
Voltemos à definição de documentário como tratamento criativo da realidade. $\mathrm{A}$ partir dela é possível estabelecer uma leitura com o olhar voltado para o sistema retórico. A realidade estaria na ordem dos valores, da doxa, podendo ser entendida como pertencente ao universo da memória discursiva. A invenção, disposição, elocução e ação estariam encerradas na ideia de tratamento criativo.

Pois bem, a realidade em Dziga Vertov é a exaltação do homem soviético e de um sistema político moderno e progressista. Esse seria o depositório da invenção. Por sua vez, o tratamento criativo perfaz a ação, a elocução e a disposição, esta última tendo primazia na mise-en-scène vertoviana, por intermédio da montagem e suas potencialidades. A Revolução Kinoks e o Cine-Olho se constituem, à vista disso, em inovações técnicas, que "entregam nas mãos dos partidários e trabalhadores do cine registro documental sonoro uma arma poderosa na luta por um outubro não encenado" (VERTOV, 1929 apud XAVIER, 2008, p. 266).

\section{Referências}

ALVARENGA, Nilson Assunção; CONCEIÇÃO, Pedro Nogueira. Dziga Vertov e as vanguardas cinematográficas: o construtivismo russo em diálogo com o impressionismo francês. In: JÚNIOR, Carlos Pernisa (org.). Vertov: o homem e sua câmera. Rio de Janeiro: Mauad X, 2009, p. 73-85.

AMOSSY, Ruth. A argumentação no discurso. Coordenação da equipe de tradução: Eduardo Lopes Piris e Moisés Olímpio-Ferreira. São Paulo: Contexto, 2018.

ARISTÓTELES. Retórica. Tradução: Edson Bini. São Paulo: Edipro, 2011.

COMOLLI, Jean-Louis. Ver e poder: a inocência perdida: cinema, televisão, ficção, documentário. Seleção e organização: Cesar Guimarães e Rubens Caixeta. Tradução: Agustin de Tuguy, Oswaldo Teixeira e Rubens Caixeta. Belo Horizonte: Ed.UFMG, 2008.

DANBLON, Emmanuelle. L'homme rhétorique: culture, raison, action. Paris: Les Éditions du Cerf, 2013.

FIORIN, José Luiz. Figuras de retórica. São Paulo: Contexto, 2016.

KRACAUER, Siegfried. De Caligari a Hitler: uma história psicológica do cinema alemão. Tradução: Tereza Ottoni. Rio de Janeiro: Zahar, 1988.

MEYER, Michel. A retórica. Tradução: Marly N. Peres. São Paulo: Ática, 2007.

NICHOLS, Bill. Introdução ao documentário. Tradução: Mônica Saddy Martins. 5.ed. Campinas: Papirus, 2014.

ORLANDI, Eni Pulccinelli. Análise de discurso: princípios \& procedimentos. 12.ed. Campinas: Pontes Editores, 2015.

PERELMAN, Chaïm; OLBRECHTS-TYTECA, Lucie. Tratado da argumentação: a nova retórica. Tradução: Maria Ermantina Galvão. 3.ed. São Paulo: Martins Fontes, 2014. 
REBOUL, Olivier. Introdução à retórica. Tradução: Ivone Castilho Benedetti. 2.ed. São Paulo: Martins Fontes, 2004.

XAVIER, Ismail. A experiência do cinema: antologia. 4.ed. Rio de Janeiro: Edições Graal: Embrafilmes, 2008.

XAVIER, Ismail. O discurso cinematográfico: a opacidade e a transparência. 6.ed. São Paulo: Paz e terra, 2014. 